\title{
Water Debt indicator reveals where agricultural water use exceeds sustainable levels
}

\author{
Marta Tuninetti ${ }^{1}$, Stefania Tamea ${ }^{1}$, Carole Dalin ${ }^{2}$
}
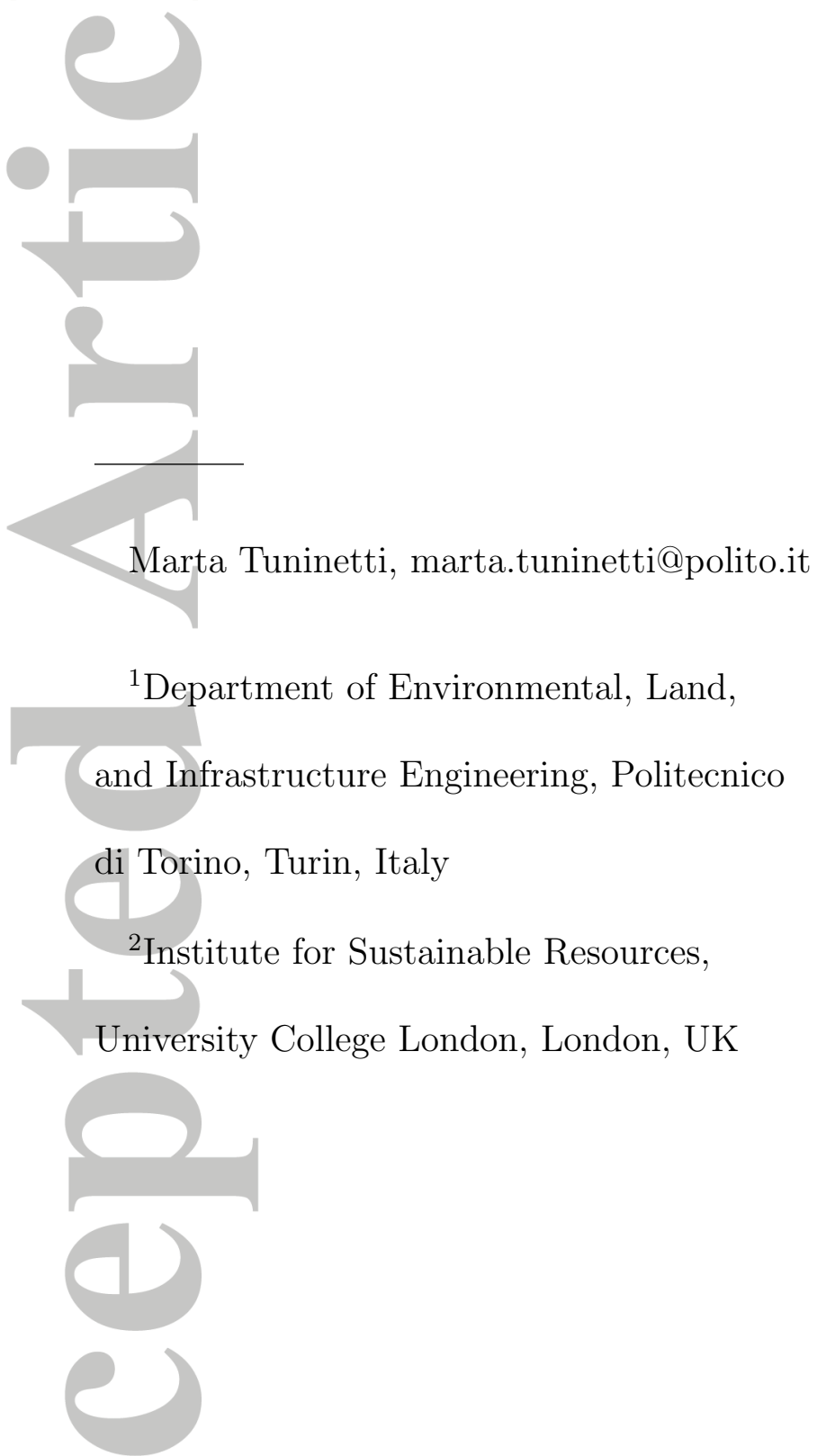

This article has been accepted for publication and undergone full peer review but has not been through the copyediting, typesetting, pagination and proofreading process, which may lead to differences between this version and the Version of Record. Please cite this article as doi: 10.1029/2018WR023146

(C)2019 American Geophysical Union. All Rights Reserved. 
Abstract. Agriculture overexploits water resources in many regions, as water stress metrics highlight. Tracing back the causes of water overuses and separately accounting for soil water, surface- and ground-water resources is an open challenge to monitor the sustainability of agricultural water use. We introduce the "Water Debt repayment time" indicator, measuring the time required to replenish water resources used for annual crop production. This indicator disentangles source-and crop-specific water overuses at a high spatial resolution. Globally, we find that wheat and rice production critically overuses groundwater resources, and cotton production overuses both surfaceand ground-water. Locally, unsustainable production is found over the Sabarmati basin and in the Chao Phraya basin, where the repayment time exceeds 5 years in many cultivated areas. Critical overuses are also found over the High Plain and Indo-Gangetic Plains, where the repayment times reach 50 years. Unsustainable irrigation is often a consequence of growing crops during local dry seasons.

\section{Keypoints:}

- The Water Debt evaluates the time required for the hydrological cycle to renew the water used for annual crop production.

- The Water Debt complements the Water Footprint indicator in sustainability assessments.

- The Water Debt unpacks the spectrum of crop responsibilities behind unsustainable freshwater use.

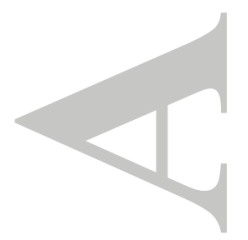

(C)2019 American Geophysical Union. All Rights Reserved. 


\section{Introduction}

Water is a renewable but finite resource, essential to all human activities and environmental processes. At the global level, we are currently using only $10 \%$ of the maximum available renewable freshwater resources and $30 \%$ of the rainfall stored in soil and vegetation [Oki and Kanae, 2006]. However, water availability is a major factor constraining humanity's ability to meet food requirement and energy needs [D'Odorico et al., 2018]; water scarcity is a major issue across global and national geopolitical agendas. Indeed, it has been shown that two billion people are living in highly water-stressed areas [Kummu et al., 2016], and two thirds of the global population live under severe water-stress conditions for at least one month a year [Mekonnen and Hoekstra, 2016]. Moreover, the intensification of surface and groundwater use in the last decades, especially for irrigation purposes [Falkenmark and Rockström, 2004], has led to staggering levels of water depletion in important aquifers [Gleeson et al., 2012; Dalin et al., 2017] and river systems [Rockström, 2003; Vörösmarty et al., 2010] worldwide, with consequent threats for natural ecosystems. Hence, balancing water demand with availability is a great challenge of mankind.

The General Assembly of the United Nations has set seventeen Sustainable Development Goals (SDGs) to stimulate action to improve human well-being and protect the planet toward year 2030 [Assembly, 2015]. Specifically, SDG target 6.4 aims at ensuring sustainable use of water resources in order to reduce the number of people suffering from water scarcity [Hoekstra, 2017; Vanham et al., 2018]. In this study, we propose a quantitative answer to this urgent matter of monitoring the sustainability of agricultural water foot-

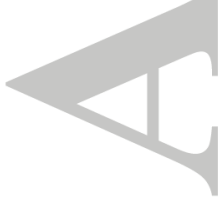

(C)2019 American Geophysical Union. All Rights Reserved. 
print (i.e., amount of water used for crop production Mekonnen and Hoekstra [2011]). We define water use for annual crop production as unsustainable when it exceeds the amount of water annually available from the local water cycle. When local availability is exceeded, a certain time is required to replenish the water resource that has been used to achieve the annual crop production. We call this the "Water Debt repayment time". This indicator builds upon a broad context of well-known water shortage and water scarcity metrics, and aims at providing a physical quantification, i.e. the measure of the time required to replenish the water resource, splitting the role of soil-, surface-, and ground-water, and to assess major responsibilities behind the overuse of water resources in agriculture, through crop-specific and spatially-explicit analysis.

In the last decades, a large number of indicators has been introduced to monitor the (mis)match between water demand and availability [Hanasaki et al., 2008; Wada et al., 2010; Wada and Bierkens, 2014; Vanham et al., 2018]. These studies underpinned regions with major water insecurity through analyses at country [Seckler et al., 1999] or grid level [Mekonnen and Hoekstra, 2016; Soligno et al., 2017], on annual [Wada and Bierkens, 2014] or monthly basis [Hoekstra et al., 2012; Scherer and Pfister, 2016], also integrating the two temporal scales [Brauman et al., 2016] and providing outlooks to possible future scenarios [Wada and Bierkens, 2014]. Most water-scarcity metrics, or criticality ratios, are based on risk categories, e.g. "high water stress" if the use-to-availability ratio is higher than 0.4 and "very high water stress" if greater than 0.8 [Alcamo et al., 2000]. Other metrics introduced a threshold to define water scarcity conditions. For instance, the Falkenmark indicator [Falkenmark, 1989] measures the number of people per unit flow of available freshwater, considering $1700 \mathrm{~m}^{3} / \mathrm{cap} / \mathrm{yr}$ as a threshold to define a situation (C)2019 American Geophysical Union. All Rights Reserved. 
of "water scarcity". In the framework of life cycle assessment, other indicators have been introduced [Kounina et al., 2013] to assess the potential environmental impact of water use. These indicators aim at quantifying the potential impact based on freshwater use inventory schemes [Boulay et al., 2011] weighted by local characterization factors which transform inventory flows into environmentally equivalent flows [Pfister et al., 2011]. In this context, Yano et al. [2016] proposed a local "water unavailability" factor to weight the water footprint of agriculture based on water availability, hence providing a picture of crop production sustainability [Yano et al., 2016]. This study [Yano et al., 2016] split for the first time the impact on green, surface and ground water resources, but lacks specific analyses at the crop level and at the sub-national and sub-basin scales; moreover, the water unavailability factor does not have a physical basis. Brauman et al. [2016] identified the areas more vulnerable to water shortage by the introduction of a water depletion metric, but without looking at green water (i.e., soil moisture) scarcity, of which inherent connection with the blue water sources (i.e., surface- and ground-water resources) has been emphasized in different studies [Falkenmark, 2013; Vanham et al., 2018]. Besides, Gleeson et al. [2012] shed light on the impacts of blue water use on groundwater resources, showing that, on a global average, humans are using groundwater 3.5 times faster than a sustainable rate.

All these indicators have proven useful to assess the geographic and temporal mismatch between water demand and availability under different perspectives. However, each indicator has some shortcomings. First, water scarcity metrics generally focus only on blue water resources, without considering the interplay between blue and green water scarcity [Vanham et al., 2018]. Moreover, only in a few recent studies blue water use has been

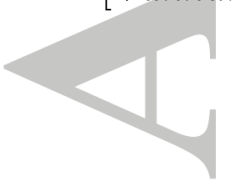

(C)2019 American Geophysical Union. All Rights Reserved. 
split into surface- and ground-water use [Wada and Bierkens, 2014], despite important differences in the access to and availability of these two water sources. Second, previous indicators mostly lack a physical interpretation, being generally based on risk categories or potential impact factors. Third, the causes of the scarcity are rarely traced back to their specific determinants, i.e., in the case of agriculture, the specific crop generating the mismatch between water use and availability. The study by Dalin et al. [2017] is the first one to analyse crop-specific responsibilities behind groundwater depletion embedded in international food trade, but also did not consider surface water use or green water use. The concept of Water Debt repayment time $(W D)$ addresses all the above mentioned issues and combines, in a single metric, all the different advances introduced by recent studies. This indicator takes into account green-, surface- and ground-water resources and enables source-specific analyses across crops and locations. The indicator is designed to unpack the multivariate spectrum of responsibilities behind local unsustainable use of freshwater resources in agriculture, enabling the assessment of water-saving strategies and the elaboration of scenarios. The $W D$ is calculated as the ratio of the source-specific water footprint (namely, the consumptive water use [Aldaya et al., 2012]) in a grid cell ( 5 arc minute resolution), to the amount of water annually available from the source in the considered cell. Green and blue water footprints are evaluated through a soil water balance model as in Tuninetti et al. [2015], but improved to distinguish between surfaceand ground-water use. Green water availability is calculated as the fraction of precipitation that infiltrates into the upper soil layer, becoming available for root water uptake.

Surface water availability equals the locally generated runoff, without accounting for the up-stream runoff in order to highlight all the areas using elsewhere-generated water re-

(C)2019 American Geophysical Union. All Rights Reserved. 
sources, which can be otherwise hidden by the upstream dependency. Finally, ground water availability is calculated as the amount of rainfall that recharges the aquifer matrix.

Annual crop production is defined as sustainable with respect to local water resources when the associated water footprint is lower or equal to the annual water availability. In this case, $W D$ is shorter than or equal to 1 year. Otherwise, if the water footprint exceeds locally available water, the annual crop production is not sustainable because the repayment time is longer than 1 year.

\section{Materials and Methods}

\subsection{Definition of the Water Debt repayment time}

The Water Debt repayment time $(W D)$ is calculated, at a 5'x5' spatial resolution for the production of year 2000, as the ratio of the cell annual water footprint, $W F_{s, c r, l}$, which is specific for each source $s$, crop $c r$, and location $l$, and the average renewable volume of water annually available in the cell, i.e.

$$
W D_{s, c r, l}=\frac{W F_{s, c r, l}}{A_{l} \cdot R_{s, l}} \quad[y r]
$$

where, $R_{s, l}\left[\mathrm{~m} \cdot \mathrm{yr}^{-1}\right]$ is the annual renewability rate of the water source and $A_{l}$ is the cell area. The annual renewability rate is calculated as a long-term average of the yearly $R_{s, l}$ values along the period 1987-2013. In this way, we obtain an average measure of the water availability in the cell, which smooths out potential extremely dry or extremely wet years. The water footprint estimates are computed for year 2000 because this is the most referenced year in agricultural datasets available in the literature (see Table S1). The $W F_{s, c r, l}$ estimate is obtained as the product of the local crop water footprint by source,

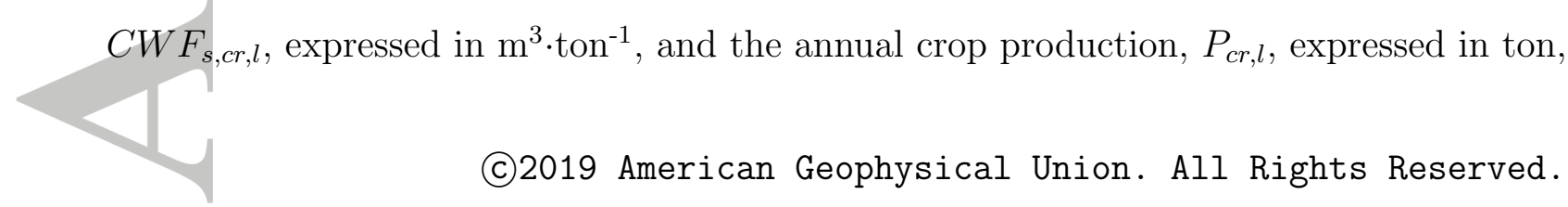


that is

$$
W F_{s, c r, l}=C W F_{s, c r, l} \cdot P r_{c r, l} \quad\left[m^{3}\right]
$$

The computation of $C W F$ is detailed in Section 2.2, while the annual production is the product between the crop yields provided by Monfreda et al. [2008] and the harvested areas derived from Portmann et al. [2010].

According to equation (1), when the annual water footprint is lower than (or equal to) the local water availability, the resource's repayment time is lower than (or equal to) 1 year and, thus, the resource is sustainably used. In fact, the annual crop production only exploits the renewable portion of the local water resource.

Conversely, when $W D>1$ year, the annual water footprint is unsustainable relatively to the local resources. This means that crops are using the water source faster than the renewability rate, with consequent depletion of the locally available stocks (i.e., groundwater storage, lakes) or implying a reliance on upstream sources in the case of surface water (i.e., cells where water scarcity can be avoided only with upstream water, whose presence is not always guaranteed). In both cases, the Water Debt is intended to seek out situations of local unsustainable production, which requires strategic planning and managements.

Using years as a metric of the local water stress allows one to understand how long it takes for the hydrological cycle to renew the water used, as if the cell was isolated and only recharged by local precipitation. Assessing the sustainable use of water resources is particularly important for the surface water bodies because many grid cells are often dependent upon upstream water originating outside their country's boundaries, meaning that important management issues on the flow can arise. Indeed, the downstream flow (C)2019 American Geophysical Union. All Rights Reserved. 
is influenced by the upstream water use and precipitation patterns. Moreover, considering that transboundary water bodies cover half of the earth's land surface [Munia et al., 2016], important issues on international co-operation and conflict may arise. In the case of groundwater, the evaluation of the $W D$ quantifies the magnitude of groundwater nonrenewable use, giving an easier perception (though the time measure) of the preciousness of the source and some insights in the implications of the Water Debt for future genera-

tions. The green $W D$ depicts the competition over rainfall water between agriculture and natural vegetation. In particular, it is intended to complete the framework of water use sustainability and to unfold synergies among different water sources.

The total $W D$ of the source $s$, arising from all the crops cultivated in the grid cell $l$, $W D_{s, l}$, equals the sum of debts generated by each crop and reads

$$
W D_{s, l}=\sum_{c r=1}^{c r=9} W D_{s, c r, l} .
$$

Owing to the simultaneous replenishment of soil-, surface- and ground-water by precipitation, the total $W D$ across the threes sources, $W D_{c r, l}$, is given by the maximum $W D$ value obtained with equation 1 ), i.e.,

$$
W D_{c r, l}=\max \left(W D_{s m, c r, l}, W D_{s w, c r, l}, W D_{g w, c r, l}\right)
$$

where $s m, s w$ and $g w$ indicate the soil moisture, surface water and groundwater, respectively. The $W D$ value at country, regional, or global scale, referred to a single crop $\mathrm{cr}$ and source $s$ is evaluated as a production-weighted mean, i.e.

$$
W D_{s, c r, L}=\frac{\sum_{l \in L} W D_{s, c r, l} \cdot P r_{c r, l}}{\sum_{l \in L} P r_{c r, l}}
$$

where $L$ is the ensemble of cells in the area of interest. In turn, if all crops are considered together, the $W D$ in the area (equation 3 ) is weighted by the water volume used by all

(C)2019 American Geophysical Union. All Rights Reserved. 
crops in the cell (or cell water footprint), i.e.

$$
W D_{s, L}=\sum_{l \in L}\left(W D_{s, l} \cdot \frac{W F_{s, l}}{\sum_{l \in L} W F_{s, l}}\right) .
$$

\subsection{Green and blue crop water footprint}

The water volume from source $s$ that is used to produce a ton of crop $\mathrm{cr}$ in a given place $l$ (i.e., country, province or grid cell) is measured by the crop water use or crop water footprint $\left(C W F_{s, c r, l}\right)$ [Aldaya et al., 2012; Tuninetti et al., 2015]. $C W F_{s, c r, l}$ equals

the water depth evapotranspired during all the growing seasons in a year from source $s$, i.e. $E T_{s, c r, l}\left(\right.$ in $\left.^{3} \cdot \mathrm{ha}^{-1}\right)$, divided by the annual crop yield, $Y_{c r, l}$ (in ton $\cdot \mathrm{ha}^{-1}$ ), namely

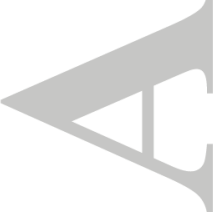

$$
C W F_{s, c r, l}=\frac{E T_{s, c r, l}}{Y_{c r, l}} \quad\left[\frac{m^{3}}{t o n}\right]
$$

We compute the crop water footprint of nine crops with a soil water balance model, at the cell level on a 5'x5' arc min grid basis [Tuninetti et al., 2015]. The reference years for the analyses are 1996-2005 with time-varying data averaged over the period and with additional data (areas, agricultural data, etc.) referred to the year 2000. Further details on model set up are available in Tuninetti et al. [2015] and a description of the main data sources is given in Table S1. Validation and uncertainty assessment of the methodology used to estimate $C W F$ can be found in Tuninetti et al. [2015, 2017]. Crop water footprint can originate from soil moisture, and surface- or ground-water bodies, i.e. blue water. The distinction between rainfed and irrigated agriculture has been derived from the MIRCA2000 dataset [Portmann et al., 2010]. While usually the two sources of blue water are computed together [Aldaya et al., 2012], here we partition the two contributions proportionally to the areas equipped for irrigation with surface water $\left(A E I_{s w, l}\right)$

and groundwater $\left(A E I_{g w, l}\right)$. These areas are available in the Global Map Irrigation Area (C)2019 American Geophysical Union. All Rights Reserved. 
(GMIA) dataset [Siebert et al., 2015]. We assume that the ratio of $C W F_{g w, c r, l}\left(C W F_{s w, c r, l}\right)$ to total blue water footprint $\left(C W F_{b, c r, l}\right)$ is equal to the ratio of $A E I_{g w, l}\left(A E I_{s w, l}\right)$ to $A E I_{l}$,

i.e.

$$
C W F_{s, c r, l}=\frac{A E I_{s, l}}{A E I_{l}} \cdot C W F_{b, c r, l}
$$

with $s=s w, g w$. This assumption may bring uncertainty in the estimation of surfaceand ground-water uses if actual and potential use of irrigation in equipped areas differ, or if the ratio of ground- to surface-water irrigation varies across crop plots or seasons in the same area Siebert et al. [2010]. However, our assumption is supported by the rational behind the dataset construction: if the extent of area equipped for irrigation with water from the different sources was unknown but irrigation water use from different sources was reported, then the water use statistics were used to downscale the irrigated area statistics (for example, if 20 percent of irrigation water use was from groundwater, then it was assumed that also 20 percent of area equipped for irrigation was irrigated with groundwater) [Siebert et al., 2005]. Recently, many studies have used the $A E I$ ratio to compute the irrigation crop water use per water source [Siebert et al., 2010; Döll et al., 2012; Doell et al., 2014], although no differentiation among crops has been proposed.' Results of groundwater use for irrigation purposes at the country scale obtained in this study have been compared with the estimates provided by Wada et al. [2016] for total crop production (Figure S2). The estimates compare well, especially for the major groundwater-consuming countries. It should be noted that indications of actual irrigation at the global scale are generally lacking, but if local data were available, they could be used to derive a specific and more precise measure of surface- and ground-water use.

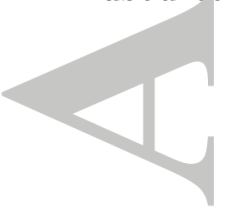

(C)2019 American Geophysical Union. All Rights Reserved. 


\subsection{Renewability rate of water resources}

Renewable freshwater is the water flow generated from precipitation that is available to meet human and ecosystem needs [Jansson et al., 1999]. Renewable soil moisture, renewable surface water, and renewable groundwater, are derived from the WaterGAP $2.2 \mathrm{~b}$ model [Müller Schmied et al., 2014] run with a "no use" setting to simulate the natural recharge rates of each source.

Renewable soil moisture is the fraction of precipitation, net of surface runoff and groundwater recharge, that infiltrates into the upper soil layer and recharges the soil water storage, becoming available for root water uptake and evapotranspiration.

Renewable surface water is the net cell surface runoff, produced by the fraction of precipitation within the cell that flows to surface water bodies minus the evaporation from lakes and wetlands. It is negative when evaporation is larger than runoff, which happens occasionally in dry regions of Egypt, Botswana, and Malawi, where precipitation is lower than the overall evapotranspiration/evaporation losses from land and water bodies. Negative monthly values of net runoff are set to zero in $3 \%$ of the cultivated grid cells worldwide, in order to avoid computational problems in the $W D$ evaluation. In the present study, we did not distinguish between the unsustainable use of the total flow and the erosion of the environmental flow due to lack of precise estimates in the literature.

Moreover, given that information on groundwater flows between cells are limited, the groundwater recharge cannot contribute to the local runoff generation [Müller Schmied et al., 2014].

Renewable groundwater is the recharge originated from precipitation that deeply percolates the soil layers and reaches the aquifer. The recharge can be both local (coming (C)2019 American Geophysical Union. All Rights Reserved. 
from surface water) and diffuse (coming from the unsaturated soil). The renewability rates of each water source are taken as the annual volumes of renewable water. Estimates from the WaterGAP 2.2b model (in $\mathrm{m}^{3} / \mathrm{m}^{2}$ ) are given as gridded data at 30 'x30' spatial resolution, then values are considered uniform over each grid cell and downscaled to the finer (5'x5') grid. Monthly values from 1987 to 2013 (centred around year 2000) have been used to construct long-term average monthly values, then cumulated over the year to define the annual renewability rates.

\section{Results}

\subsection{Global assessment}

We summarize the (mis)match between global crop water use and water availability for nine major crops in Figure 1, which shows global averages of water use efficiencies (or crop water footprint, $C W F$ ), crop water consumption (or water footprint, $W F$ ) and the Water Debt repayment time $(W D)$. An average of $3313 \mathrm{~km}^{3} / \mathrm{yr}$ of water has been required to produce nine major crops (i.e., wheat, rice, maize, soybean, barley, potatoes, sugarcane, sugar beet, and cotton) over the 1996-2005 period. Eighty percent of the total volume comes from soil moisture and nearly $20 \%$ from surface- $(60 \%)$ and ground-(40\%) water resources (Figure 1B). These crops present different levels of water-related sustainability (Figure 1C), reflected in the different WDs incurred by their annual production. Maize, soybean, barley, potatoes, and sugar crops (providing $32 \%$ of the global food calories [D'Odorico et al., 2014]) are classified as water-sustainable crops on a global average, because their annual production requires an amount of water that does not exceed the amount annually available from the water resources. Conversely, wheat and rice (providing another $36 \%$ of the global food calories [D'Odorico et al., 2014]), together with cotton, are 
water-unsustainable crops because they consume more water than that locally available. Indeed, the mismatch between crop water use and availability produces a $W D$ larger than 1 year, e.g. it reaches 4 years for the groundwater used for rice and cotton production (Figure 1C). Cotton production also unsustainably relies on surface water bodies, showing an average $W D$ of 2 years, despite consuming only $32 \mathrm{~km}^{3}$ of surface water (Figure $1 \mathrm{~B}$ ), a much lower amount than that required by wheat $\left(56 \mathrm{~km}^{3}\right)$ and rice $\left(196 \mathrm{~km}^{3}\right)$. The mismatch between water use and availability occurs for different reasons, such as (i) low crop water-use efficiency (or large unit water footprint), (ii) intense crop production that implies large water consumption, and (iii) slow local renewability rate of water resources. The first two factors define the pressure on water resources, the third factor reflects how much pressure can be supported by the local hydrological cycle and, thus, combination of these factors determine the level of $W D$. As shown in Figure 1A, the globally-average water use efficiency varies significantly across the nine crops. Cotton is by far the most water-intensive crop (nearly $4000 \mathrm{~m}^{3}$ ton $^{-1}$ ), but sums to a relatively small global water use $\left(192 \mathrm{~km}^{3}\right)$ compared to other less water-intensive crops such as rice $\left(1435 \mathrm{~m}^{3} \mathrm{ton}^{-1}\right.$, $790 \mathrm{~km}^{3}$ total $)$ and wheat $\left(1529 \mathrm{~m}^{3} \operatorname{ton}^{-1}, 845 \mathrm{~km}^{3}\right)$. Over seventy percent of the irrigation water used to grow the nine crops is for rice $\left(289 \mathrm{~km}^{3}\right)$ and wheat $\left(120 \mathrm{~km}^{3}\right)$. Barley, potatoes and sugar crops are all relatively less water-intensive and lead to a relatively lower global water use, thus ensuring a sustainable use of water resources (Figure 1C). The global-scale values of water use and $W D$ shown in Figure 1 give a first insight into the water-sustainability of the different crops. However, as shown in Figure 2 (and in Figure S1, when all water sources are considered together) $W D$ s greatly vary in space, revealing areas of higher or lower water-use sustainability.

(C)2019 American Geophysical Union. All Rights Reserved. 


\subsection{Geography of the (mis)match between surface water use and local runoff}

We consider that annual crop production incurs water debt with surface water resources when demand for surface water irrigation exceeds the locally generated runoff. Since we focus on the local sustainability of water use, we do not consider upstream flows as available sources in downstream cells. This assumption may lead to overestimates of $W D$ in downstream cells, but it allows to clearly underpin all the areas that are not locally sustainable because of (i) the overexploitation of local water resources, (ii) the low renewability rate of local water resources, or (iii) the dependence on upstream water resources, which is transboundary in some watersheds (e.g., Nile and Rio Grande Munia et al. [2017]). Also, in this study we do not account for the environmental flow requirements, which could fur-

ther increase the Water Debt. However, estimates of the environmental flow requirement are not strictly defined in the literature: these uncertainties can inflate the water debt uncertainty. In order to reveal the different levels of water sustainability, we calculate the surface water footprint and the $W D$ both at the grid and basin level. These two different outputs highlight the importance of scale in water resources management. In fact, the surface $W D$ at the basin scale is calculated as the basin's surface water footprint divided by the total runoff generated within the basin.

At the basin level, we find that all basins sustainably provide water to the nine crops examined (Table 1); although sustainability issues may arise due to the water used by other crops/sectors and if considering environmental flows requirements. The basins of Sabarmati in India and Chao Phraya in Thailand show the least sustainable surface water footprints, showing longer $W D$ than all the other basins: i.e., 0.33 and 0.22 year (Table 1, or 120 and 79 days, respectively). The surface water footprints of these basins are 24 (C)2019 American Geophysical Union. All Rights Reserved. 
and $7.8 \mathrm{~km}^{3}$, respectively. The surface water footprint of the Sabarmati basin is smaller than that of Indus and Yangze basins, but a longer $W D$ is required because of the lower surface water availability. Sugarcane and rice are the crops mostly responsible for the large repayment time there. Locally, the replenishment time is longer than 1 year in the North West and South of the basin, but $W D$ values are always shorter than 8 years. Conversely, longer $W D$ s are found across the Nile Delta, where $W D$ reaches 20 years, due to the cultivation of rice, maize, and wheat (Figure 2B). Here, irrigation demand is mainly reliant upon upstream cells, as confirmed by the study by Munia et al. [2017] and by a lower $W D$ when the whole basin is considered. Crop production across the Indus River Basin relies on locally unsustainable water use, with $W D$ longer than 20 years in some cells in the East of the basin. We found that wheat, rice, and sugarcane production draws most of the water annually available from locally generated runoff. The local reduction of river flow due to withdrawals and the low renewability rates are responsible for such large $W D$ values. However, when we consider the water debt at the basin scale, we obtain an average $W D$ of 0.15 year (or 53 days, Table 1 ). Other vulnerable areas are found in

China, along the Tarim River, where the largest $W D$ s are mainly due to rice production, and along the Yellow River, where rice and maize are most responsible for the overuse of surface water. Finally, due to the diversions of the Amu Darya and Syr Daria rivers to grow cotton and rice in an arid region, the areas close to the Aral Sea have undergone serious environmental damages [Pekel et al., 2016] and show high WD.

(C)2019 American Geophysical Union. All Rights Reserved. 


\subsection{Geography of the (mis)match between groundwater use and aquifer}

recharge

Unsustainable use of groundwater resources occurs when the groundwater footprint exceeds the annual recharge of the aquifers. When this happens, the groundwater storage becomes locally depleted. Over half of the global groundwater use for the nine crops originates from just four major aquifers, namely the Indo-Gangetic Plain (41\%), U.S. High Plains (8\%), North China Plain (5\%), and the California Central Valley (1.6\%) aquifers. The highest groundwater use is found over the Indo-Gangetic plain (100 km $\left.{ }^{3} / \mathrm{yr}\right)$, where $64 \%$ of the Indian and Pakistan crop production is located. The average groundwater $W D$ generated by annual crop production over the Indo-Gangetic plain aquifer is around 13 years, but some zones also reach extreme $W D$ values of 50 years (Figure 2C). Hence, water use for irrigation in these areas is highly unsustainable, markedly depleting the aquifer and extending the impact of crop water use to future generations. In particular, the largest WD are found in the Upper Ganges, while the groundwater in the Lower Ganges appears to be sustainably exploited, due to lower water use and faster recharge rates. Over the U.S. High Plain area, the groundwater exploitation is significant, as previously shown by Marston et al. [2015]. The average $W D$ is around 7.2 years, but larger $W D$ s are found in the central and southern part of the High Plain (i.e., Kansas and Texas mostly), where the renewability rate is lower than that in the North. Among the study crops, maize and cotton are the main responsible for the groundwater depletion, as Dalin et al. [2017] also pointed out. Over the California Central Valley, groundwater $W D$ increases from North

(2 years, due to rice and maize production) to South (9 years, due to cotton production). Groundwater-fed crop production in the North China Plain appears to be unsustainable

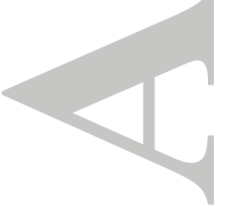

(C)2019 American Geophysical Union. All Rights Reserved. 
as well, but the arisen groundwater $W D$ are relatively smaller, i.e. $W D$ of 1.5 year, mainly associated with rice and wheat production. Our estimates of unsustainable use of groundwater resources are in accordance with previous studies, e.g. the groundwater footprint indicator developed by Gleeson et al. [2012]; and the crops highlighted in Figure 2C compare well with the groundwater depletion responsibilities found by Dalin et al. [2017].

\subsection{Geography of the (mis) match between green water use and soil moisture}

Green water use sustains the vast majority of the water demand coming from the nine study crops. Green water use sustainably relies on local soil moisture, as shown in Figure 2A. Indeed, when soil moisture is lower than the crop water requirement, the plant reduces its evapotranspiration rate and biomass growth. Therefore, green water use is always lower or equal to the soil moisture availability along the year. Notwithstanding, we calculate the $W D$ also for the green water to show regions where precipitation is mainly exploited by agriculture rather than natural vegetation and to allow one for comparisons with the $W D$ s arisen by the surface and ground water use shown (Figures 2B,C). In most productive regions, we found green $W D$ s close to one year. The largest green water exploitation occurs in the US Midwest (black circle, Figure 2A), where nearly $40 \%$ of the national production of the nine considered crops is located. Precipitation is the most important source for crops there (especially, for soybean and maize), which use it for 6-8 months per year. France, Germany, and Italy show similar conditions, but soil moisture exploitation is more spread out across these countries. Northern India presents a green $W D$ larger than

8 months due to wheat, sugarcane, and rice production, while Eastern China exhibits a green $W D$ higher than 6 months mostly because of maize production. All the cells 
showing small green $W D$ s but large blue $W D$ s (see Figures $2 \mathrm{~B}, \mathrm{C}$ ) reflect that growing crops during the local dry season is often associated with unsustainable irrigation. In the US, China, India, Sudan, and Turkmenistan we found different cells having a green $W D$ shorter than 3 months and a surface $W D$ larger than 10 years.

\subsection{Countries showing different levels of water use (un)sustainability}

The $W D$ varies both across countries growing the same crop and among crops grown in the same country. In fact, the same country can produce a range of crops with different levels of water-related sustainability depending on, e.g., the crop type, the cropping area location in the country, the cropping calendar. In Figure 3, we show the source-specific $W D$ of the top-three producing countries of each crop. Annual wheat production unsustainably uses groundwater both in China ( $W D$ of 2.2 year) and India ( $W D$ of 1.5 year), which together account for over $30 \%$ of the global wheat production. These countries also account for over $60 \%$ of rice production, which contributes itself to the over-exploitation of the Chinese and Indian aquifers. In particular, the annual groundwater footprint for rice in India $\left(46 \mathrm{~km}^{3}\right)$ requires 1.3 years to be replenished, while the much lower annual groundwater footprint of China $\left(25 \mathrm{~km}^{3}\right)$ arises a groundwater $W D$ of 7.5 years, due to the slower recharge rate of its aquifers compared to the Indian ones. Another $10 \%$ of global rice production is located in Indonesia, where it is sustainable thanks to the large fraction of green water use (over $75 \%$ of total rice water use). Surprisingly, wheat and rice production in India show a similar groundwater $W D$, although rice uses nearly twice as much groundwater as wheat does. The reason is that Indian rice is mostly grown

in areas where groundwater resources are recharged at faster rates. Over $60 \%$ of global maize production is located in the United States, China, and Brazil. The United States (C)2019 American Geophysical Union. All Rights Reserved. 
produce twice as much maize as China with a three-times larger groundwater use per unit weight, but generate a lower $W D$, i.e., 0.5 year versus 2.8 years, highlighting the different renewability rates of aquifers in the two countries. However, despite the sustainability on a national average, maize production in the US is responsible for major $W D$ hotspots over the California Central Valley (1.6 year) and the High Plain aquifer (2 year). Soybean, barley, and potatoes production is completely sustainable in the top-three producing countries: i.e., the repayment time is lower than 0.3 year for all sources, because production is almost entirely rain-fed and sufficient soil moisture is available during the growing season to satisfy the crop water requirement. Notably, Russia, Canada, and Germany produce nearly the same amount of barley, but with very different impacts on the soil moisture. Indeed, Russian barley production requires a $W D$ (0.02 year) much lower than those of Canada (0.04 year) and Germany (0.1 year), despite a water use per ton of crop $\left(2500 \mathrm{~m}^{3}\right.$ ton $\left.^{-1}\right)$ five times larger than those of Canada and Germany. Similarly, sugar crops production is sustainable overall thanks to the large reliance of these crops on soil water. Exception is found for sugarcane production in India, i.e. the groundwater $W D$ is around 1.2 year. Finally, over $40 \%$ of cotton production, located in China and the US, is not sustainable and depletes aquifers. Particularly, in the US the $W D$ is close to 7 years due to the large fraction of groundwater use with respect to the total volume, because of insufficient soil moisture availability during the growing season.

\section{Sustainability insights provided by the Water Debt indicator}

The adoption of the $W D$ indicator provides useful insights for water resource planning and management in critical areas and at different spatial scale. In the following, we provide three examples of $W D$ application, in order to highlight how it can be used in

(C)2019 American Geophysical Union. All Rights Reserved. 
decision-making and/or policy making. At the country scale, the $W D$ allows one to discriminate two countries showing the same water use efficiency and producing nearly the same amount of crop, but generating a different impact on water resource depending on the local water availability. For instance, India and the US produce nearly the same amount of wheat with an average $C W F$ of $1700 \mathrm{~m}^{3}$ ton $^{-1}$, but Indian production is less sustainable, showing a $W D$ of 1.5 year, 5 times longer than for the US water footprint (see Figure 3). Such difference in the $W D$ is mostly due to a different soil moisture availability during the growing season, hence determining a different blue water requirement. When considering cotton production, these two countries reverse their respective impacts on groundwater resources: i.e., the cotton $W D$ in the US is close to 8 years while it is about 0.5 year in India, despite US cotton being less water intensive than Indian cotton $(C W F$ of $4300 \mathrm{~m}^{3}$ ton $^{-1}$ versus $8500 \mathrm{~m}^{3}$ ton $^{-1}$ ). Such an inversion of impacts is due to both the larger production of cotton in the US and the lower soil moisture availability during cotton's growing season, which increases the irrigation requirement. Therefore, the production of less water-intensive crops can be unsustainable for the local available resources. The analysis of the country $W D$ can find application in different contexts, paricularly in the study of international trade and water resources globalization. Indeed, the $W D$ can highlight (un)sustainable exporters and importers. A sustainable exporter will be identified as a country with a $W D$ lower than 1, namely the amount of crop produced for export does not compromise the local water resources. A sustainable importer will be the one importing from countries that sustainably rely on water resources.

The $W D$ indicator can also provide significant insights at higher spatial resolutions, where it can be used to trace back the causes of unsustainable water use. Here, we adopt (C)2019 American Geophysical Union. All Rights Reserved. 
the $W D$ indicator to find out which crops have been most responsible for the overuse of the Aral Sea as a consequence of the diversion of the Amu Darya and Syr Darya rivers [Pekel et al., 2016]. Along the southern inflow of the Sea overuse is mostly caused by cotton production that over-exploits the local surface water resources, with some cells depleting the resource 40 times faster than it is recharged (Figure 4). Crop production in Turkmenistan shows an average $W D_{s w}$ of $21 \mathrm{yr}$. The Northern inflow of the Aral Sea (i.e., Sir Darya River) is also over-exploited for agricultural production, but lower $W D$ s are found because surface water use is lower given that it is mostly provided to rice, which is less water-intensive than cotton (i.e., $2560 \mathrm{~m}^{3} \cdot$ ton $^{-1}$ versus $5455 \mathrm{~m}^{3} \cdot$ ton $^{-1}$ ). Both rice production in Kazakhstan and cotton production in Turkmenistan could reduce their $W D_{s w}$ by cutting the crop water use to benchmark values [Mekonnen and Hoekstra, 2013]. In fact, cotton production in Turkmenistan uses $40 \%$ more water per unit weight than the global average, while rice production in Kazakhstan uses $80 \%$ more than the global average. Overall, the large $W D$ values found along the southern inflow highlight how these cells are not auto-sufficient in providing cotton with the required water and need to exploit the water coming from upstream, which can not reach the lake anymore. However, reducing the crop water footprint, i.e. increasing the crop water use efficiency, is not always the most appropriate solution to improve the water use sustainability (reduce $W D)$. As found for example for wheat production in China, the local unavailability of renewable water resources means that even relatively water-efficient crop production can rely on unsustainable water use. Indeed, some provinces where water use efficiency is already high compared to both the national and the global averages (Figure 4), still show long $W D$ s. For example, in the Xinjiang province, crop water use efficiency is (C)2019 American Geophysical Union. All Rights Reserved. 
very high (i.e., $460 \mathrm{~m}^{3} \mathrm{ton}^{-1}$ ), but groundwater use is largely unsustainable (4.7 year) due to the low recharge rate of the aquifer owing to scarce precipitation (less than 100 $\left.\mathrm{mm} \cdot \mathrm{yr}^{-1}\right)$. Similarly, in the North of the Ningxia province (Figure 4(b)), water use for wheat production is unsustainable (surface water $W D$ of 1.1 year) even though the water use efficiency $\left(600 \mathrm{~m}^{3}\right.$ ton $\left.^{-1}\right)$ is better than the national average. In the case of Ningxia province, a way to reduce $W D$ could be to transfer the wheat cultivation from North to South East where runoff is much higher, or increase the production e.g., in the Eastern provinces where soil moisture is widely available during the growing season. Nevertheless, in making these considerations other factors should also be taken into account, such as the availability of arable land and adequate labour force.

\section{Discussion and Conclusion}

The Water Debt repayment time quantifies the local mismatch between water use and availability. It provides crop- and water source- specific results, and it can be applied at different spatial scale depending on the assessment's goals. It enables comparisons between different crops types, across water sources, and among production sites. With respect to earlier indicators of water overuse, $W D$ traces back to the single crop the causes of the water overuses and separately accounts for soil water, surface- and ground-water resources.

This indicator suits the context of recently developed water scarcity and water stress metrics, but it also accounts for the interplay between green and blue water sources. For surface water resources, the $W D$ underpins all the areas where locally generated runoff is over-exploited or is not sufficient to sustain the production, hence highlighting a situation of critical stress or a dependence on upstream water bodies. In the case (C)2019 American Geophysical Union. All Rights Reserved. 
of groundwater, the Water Debt sheds light on the local depletion of the water table every time water use exceeds the aquifer's recharge rate. Finally, in the case of green water the $W D$ gives a quantitative indication about the number of months during which precipitation is exploited by agriculture rather than natural vegetation. Considering the interplay between green and blue water sources can foster a better cropping management to properly exploit available soil moisture during the growing season while protecting aquifers and river systems, and thus the natural ecosystem. Small green WDs are also important to be considered, especially when associated with large blue $W D$ s because they point out situations of scarcity along the growing season, which are not always buffered by infrastructures, especially in the African and Asian regions. In fact, a small green $W D$ implies a small use of the soil moisture along the growing season, although available along the year. This has the consequence of generating a large blue $W D$ in areas equipped for irrigation. Comparing the Water Debt of different sources help in improving the management of water resources and stimulate a finer planning of the growing season, although other variables such as the temperature plays an important role as well.

It is also worth noticing that, in general, water debts are due not only to the domestic, but also to the foreign, demand for crops, with international food trade [Tamea et al., 2014; Dalin et al., 2017] playing a role in the harshening or loosening of water resources exploitation. The Water Debt will thus be useful in characterizing the sustainability of the food trade. The $W D$ indicator enables to fairly compare the sustainability of crop production related to water resources across regions, based on the local information of water availability and different source renewability. We note that this study only focuses on a portion of agricultural production (which provides about $70 \%$ of the global caloric (C)2019 American Geophysical Union. All Rights Reserved. 
content and $66 \%$ of the proteins in global human consumption [D'Odorico et al., 2014]). Other crops, as well as other water-consuming sectors (e.g., domestic and industrial) should be considered in future studies to complete the picture of sustainability. The Water Debt repayment time indicator comes up beside the concept of the time to repay the Carbon Debt [Fargione et al., 2008] generated from land clearing to produce cropbased biofuels. Quantifying the impacts of human activities on the Earth through the time answers the question of whether humanity is currently "meeting the needs of the present generation without compromising the ability of future generations to meet their own needs" [Brundtland, 1987].

Acknowledgments. M.T. and S.T. acknowledge the funding support provided by the European Research Council (grant ERC-2014-CoG, project 647473) and C.D. acknowledges the funding support of the U.K. Natural Environment Research Council (NERC Independent Research Fellowship NE/N01524X/1). The data needed to evaluate the conclusions in the paper are presented in the paper and/or the Supplementary Materials. The data used in the current study are from cited references. The gridded source-specific

Water Debts are available at https://doi.org/10.5281/zenodo.2552523.)

\section{References}

Alcamo, J., T. Henrichs, and T. Rosch (2000), World water in 2025, World Water Series Report, 2.

Aldaya, M., A. Chapagain, A. Hoekstra, and M. Mekonnen (2012), The Water Footprint Assessment Manual: Setting the Global Standard, Taylor \& Francis.

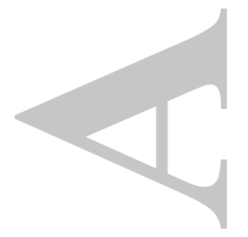

(C)2019 American Geophysical Union. All Rights Reserved. 
Assembly, U. (2015), Transforming our world: the 2030 agenda for sustainable development. resolution adopted by the general assembly on 25 september 2015 .

Boulay, A.-M., C. Bouchard, C. Bulle, L. Deschênes, and M. Margni (2011), Categorizing water for lca inventory, The International Journal of Life Cycle Assessment, 16(7), $639-651$.

Brauman, K. A., B. D. Richter, S. Postel, M. Malsy, and M. Flörke (2016), Water depletion: An improved metric for incorporating seasonal and dry-year water scarcity into water risk assessments, Elem Sci Anth, 4.

Brundtland, G. H. (1987), Report of the World Commission on environment and development:" our common future.", United Nations.

Dalin, C., Y. Wada, T. Kastner, and M. J. Puma (2017), Groundwater depletion embedded in international food trade, Nature, 543(7647), 700-704.

D'Odorico, P., J. A. Carr, F. Laio, L. Ridolfi, and S. Vandoni (2014), Feeding humanity through global food trade, Earth's Future, 2(9), 458-469.

D’Odorico, P., K. F. Davis, L. Rosa, J. A. Carr, D. Chiarelli, J. Dell'Angelo, J. Gephart, G. K. MacDonald, D. A. Seekell, S. Suweis, et al. (2018), The global food-energy-water nexus, Reviews of Geophysics.

Doell, P., H. Mueller Schmied, C. Schuh, F. T. Portmann, and A. Eicker (2014), Globalscale assessment of groundwater depletion and related groundwater abstractions: Combining hydrological modeling with information from well observations and grace satellites, Water Resources Research, 50(7), 5698-5720.

Döll, P., H. Hoffmann-Dobrev, F. T. Portmann, S. Siebert, A. Eicker, M. Rodell, G. Strassberg, and B. Scanlon (2012), Impact of water withdrawals from groundwater and surface (C)2019 American Geophysical Union. All Rights Reserved. 
water on continental water storage variations, Journal of Geodynamics, 59, 143-156.

Falkenmark, M. (1989), The massive water scarcity now threatening africa: why isn't it being addressed?, Ambio, pp. 112-118.

Falkenmark, M. (2013), Growing water scarcity in agriculture: future challenge to global water security, Philosophical Transactions of the Royal Society of London A: Mathematical, Physical and Engineering Sciences, 371 (2002), 20120,410.

Falkenmark, M., and J. Rockström (2004), Balancing water for humans and nature: the new approach in ecohydrology, Earthscan.

Fargione, J., J. Hill, D. Tilman, S. Polasky, and P. Hawthorne (2008), Land clearing and the biofuel carbon debt, Science, 319(5867), 1235-1238.

Federal Institute of Hydrology, G., Koblenz (2007), Major river basins of the world/global runoff data center.

Gleeson, T., Y. Wada, M. F. Bierkens, and L. P. van Beek (2012), Water balance of global aquifers revealed by groundwater footprint, Nature, 488(7410), 197-200.

Hanasaki, N., S. Kanae, T. Oki, K. Masuda, K. Motoya, N. Shirakawa, Y. Shen, and K. Tanaka (2008), An integrated model for the assessment of global water resourcespart 1: Model description and input meteorological forcing, Hydrology and Earth System Sciences, 12(4), 1007-1025.

Hoekstra, A. Y. (2017), Water footprint assessment: evolvement of a new research field, Water Resources Management, pp. 1-21.

Hoekstra, A. Y., M. M. Mekonnen, A. K. Chapagain, R. E. Mathews, and B. D. Richter (2012), Global monthly water scarcity: blue water footprints versus blue water availability, PLoS One, $7(2)$, e32,688.

(C)2019 American Geophysical Union. All Rights Reserved. 
Jansson, Å., C. Folke, J. Rockström, L. Gordon, and M. Falkenmark (1999), Linking freshwater flows and ecosystem services appropriated by people: the case of the baltic sea drainage basin, Ecosystems, 2(4), 351-366.

Kounina, A., M. Margni, J.-B. Bayart, A.-M. Boulay, M. Berger, C. Bulle, R. Frischknecht, A. Koehler, L. M. i Canals, M. Motoshita, et al. (2013), Review of methods addressing freshwater use in life cycle inventory and impact assessment, The International Journal of Life Cycle Assessment, 18(3), 707-721.

Kummu, M., J. Guillaume, H. de Moel, S. Eisner, M. Flörke, M. Porkka, S. Siebert, T. Veldkamp, and P. Ward (2016), The worlds road to water scarcity: Shortage and stress in the 20th century and pathways towards sustainability, Scientific Reports, 6.

Marston, L., M. Konar, X. Cai, and T. J. Troy (2015), Virtual groundwater transfers from overexploited aquifers in the united states, Proceedings of the National Academy of Sciences, 112(28), 8561-8566.

Mekonnen, M., and A. Hoekstra (2011), The green, blue and grey water footprint of crops and derived crop products, Hydrology 85 Earth System Sciences Discussions, 8(1).

Mekonnen, M., and A. Hoekstra (2013), Water footprint benchmark for crop production. Mekonnen, M. M., and A. Y. Hoekstra (2016), Four billion people facing severe water scarcity, Science Advances, 2(2), e1500,323.

Monfreda, C., N. Ramankutty, and J. A. Foley (2008), Farming the planet: 2. geographic distribution of crop areas, yields, physiological types, and net primary production in the year 2000, Global biogeochemical cycles, 22(1), GB1022.

Müller Schmied, H., S. Eisner, D. Franz, M. Wattenbach, F. T. Portmann, M. Flörke, and P. Döll (2014), Sensitivity of simulated global-scale freshwater fluxes and storages to (C)2019 American Geophysical Union. All Rights Reserved. 
input data, hydrological model structure, human water use and calibration, Hydrology and Earth System Sciences, 18(9), 3511-3538.

Munia, H., J. Guillaume, N. Mirumachi, M. Porkka, Y. Wada, and M. Kummu (2016), Water stress in global transboundary river basins: significance of upstream water use on downstream stress, Environmental Research Letters, 11(1), 014,002.

Munia, H. A., J. Guillaume, N. Mirumachi, Y. Wada, and K. Matti (2017), How downstream sub-basins depend on upstream inflows to avoid scarcity: typology and global analysis of transboundary rivers, Hydrology and Earth System Sciences Discussions, 2017, 1-26, doi:10.5194/hess-2017-537.

Oki, T., and S. Kanae (2006), Global hydrological cycles and world water resources, Science, 313(5790), 1068-1072.

Pekel, J.-F., A. Cottam, N. Gorelick, A. S. Belward, et al. (2016), High-resolution mapping of global surface water and its long-term changes, Nature, 540(7633), 418-422.

Pfister, S., P. Bayer, A. Koehler, and S. Hellweg (2011), Environmental impacts of water use in global crop production: hotspots and trade-offs with land use, Environmental Science \& Technology, 45(13), 5761-5768.

Portmann, F. T., S. Siebert, and P. Döll (2010), Mirca2000global monthly irrigated and rainfed crop areas around the year 2000: A new high-resolution data set for agricultural and hydrological modeling, Global biogeochemical cycles, 24(1), GB1011.

Rockström, J. (2003), Water for food and nature in drought-prone tropics: vapour shift in rain-fed agriculture, Philosophical Transactions of the Royal Society of London B: Biological Sciences, 358(1440), 1997-2009.

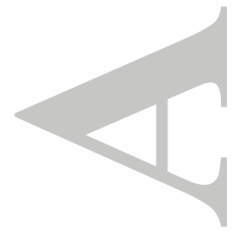

(C)2019 American Geophysical Union. All Rights Reserved. 
Scherer, L., and S. Pfister (2016), Dealing with uncertainty in water scarcity footprints, Environmental Research Letters, $11(5), 054,008$.

Seckler, D., R. Barker, and U. Amarasinghe (1999), Water scarcity in the twenty-first century, International Journal of Water Resources Development, 15(1-2), 29-42.

Siebert, S., P. Döll, J. Hoogeveen, J.-M. Faures, K. Frenken, and S. Feick (2005), Development and validation of the global map of irrigation areas, Hydrology and Earth System Sciences Discussions, 2(4), 1299-1327.

Siebert, S., J. Burke, J.-M. Faures, K. Frenken, J. Hoogeveen, P. Döll, and F. T. Portmann (2010), Groundwater use for irrigation-a global inventory, Hydrology and Earth System Sciences, $14(10), 1863-1880$.

Siebert, S., M. Kummu, M. Porkka, P. Döll, N. Ramankutty, and B. R. Scanlon (2015), A global data set of the extent of irrigated land from 1900 to 2005, Hydrology and Earth System Sciences, 19(3), 1521-1545.

Soligno, I., L. Ridolfi, and F. Laio (2017), The environmental cost of a reference withdrawal from surface waters: Definition and geography, Advances in Water Resources, 110, 228237.

Tamea, S., J. Carr, F. Laio, and L. Ridolfi (2014), Drivers of the virtual water trade, Water Resources Research, 50(1), 17-28.

Tuninetti, M., S. Tamea, P. D’Odorico, F. Laio, and L. Ridolfi (2015), Global sensitivity of high-resolution estimates of crop water footprint, Water Resources Research, 51(10), $8257-8272$.

Tuninetti, M., S. Tamea, F. Laio, and L. Ridolfi (2017), A fast track approach to deal with the temporal dimension of crop water footprint, Environmental Research Letters,

(C)2019 American Geophysical Union. All Rights Reserved. 
$12(7), 074,010$.

Vanham, D., A. Y. Hoekstra, Y. Wada, F. Bouraoui, A. de Roo, M. Mekonnen, W. van de Bund, O. Batelaan, P. Pavelic, W. Bastiaanssen, et al. (2018), Physical water scarcity metrics for monitoring progress towards sdg target 6.4: An evaluation of indicator 6.4. 2 level of water stress, Science of the Total Environment, 613, 218-232.

Vörösmarty, C. J., P. B. McIntyre, M. O. Gessner, D. Dudgeon, A. Prusevich, P. Green, S. Glidden, S. E. Bunn, C. A. Sullivan, C. Reidy Liermann, et al. (2010), Global threats to human water security and river biodiversity, Nature, 467(7315), 555.

Wada, Y., and M. F. Bierkens (2014), Sustainability of global water use: past reconstruction and future projections, Environmental Research Letters, 9(10), 104,003.

Wada, Y., L. P. van Beek, C. M. van Kempen, J. W. Reckman, S. Vasak, and M. F. Bierkens (2010), Global depletion of groundwater resources, Geophysical Research Letters, $37(20)$.

Wada, Y., I. E. de Graaf, and L. P. van Beek (2016), High-resolution modeling of human and climate impacts on global water resources, Journal of Advances in Modeling Earth Systems, 8(2), 735-763.

Yano, S., N. Hanasaki, N. Itsubo, and T. Oki (2016), Potential impacts of food production on freshwater availability considering water sources, Water, 8(4), 163.

Steffen, W., K. Richardson, J. Rockström., S. E. Cornell, I. Fetzer, E. Bennett, R. Biggs, S. R. Carpenter, W. De Vries, C. A. De Wit, and others (2015), Planetary boundaries: Guiding human development on a changing planet, Science, $347(6223), 1259855$.

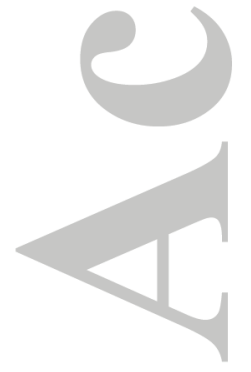

(C)2019 American Geophysical Union. All Rights Reserved. 
Table 1. Surface water footprint and water debt of major river basins, which sustain $50 \%$ of the global surface water footprint due to the cultivation of the nine crops. Basin delimitation is provided by the GRDC repository Federal Institute of Hydrology [2007].

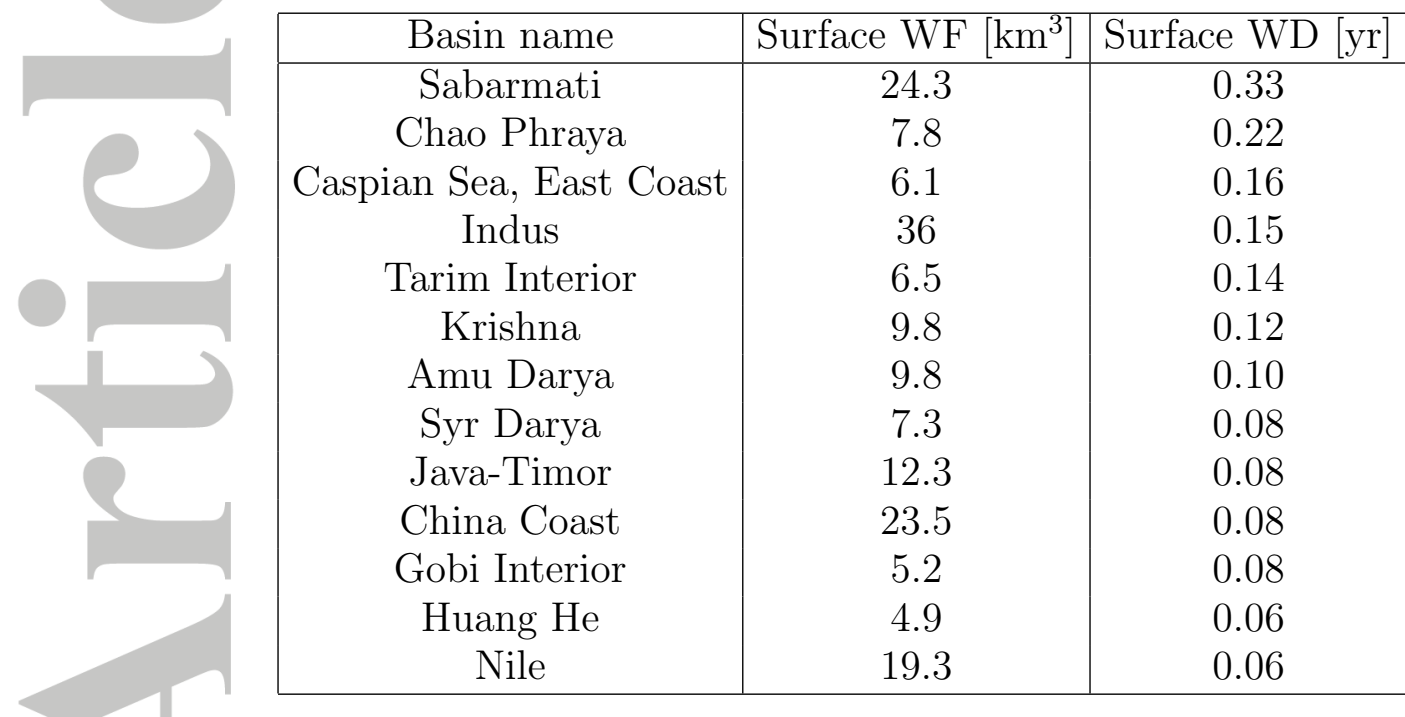

(C)2019 American Geophysical Union. All Rights Reserved. 


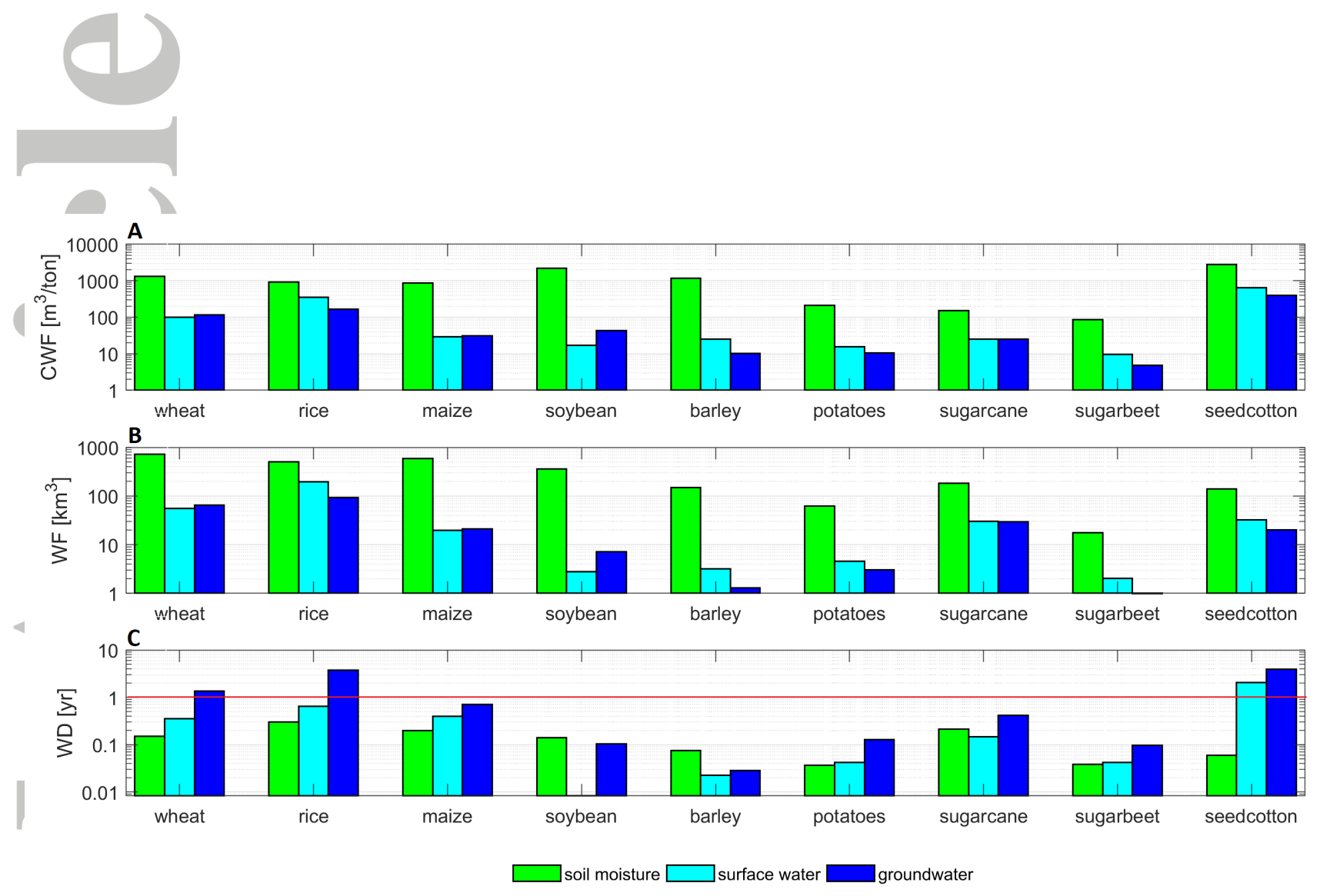

Figure 1. Global picture of crop water use and its sustainability. Globally averaged crop water footprint $(C W F$, panel A), total water footprint (WF, panel B), and globally averaged water debt repayment time $(W D$, panel $\mathrm{C})$ to recover the water debt for each crop and per water source. The red line in panel $\mathrm{C}$ highlights $W D$ of 1 year and, thus, the boundary between sustainable and unsustainable water use.

(C)2019 American Geophysical Union. All Rights Reserved. 

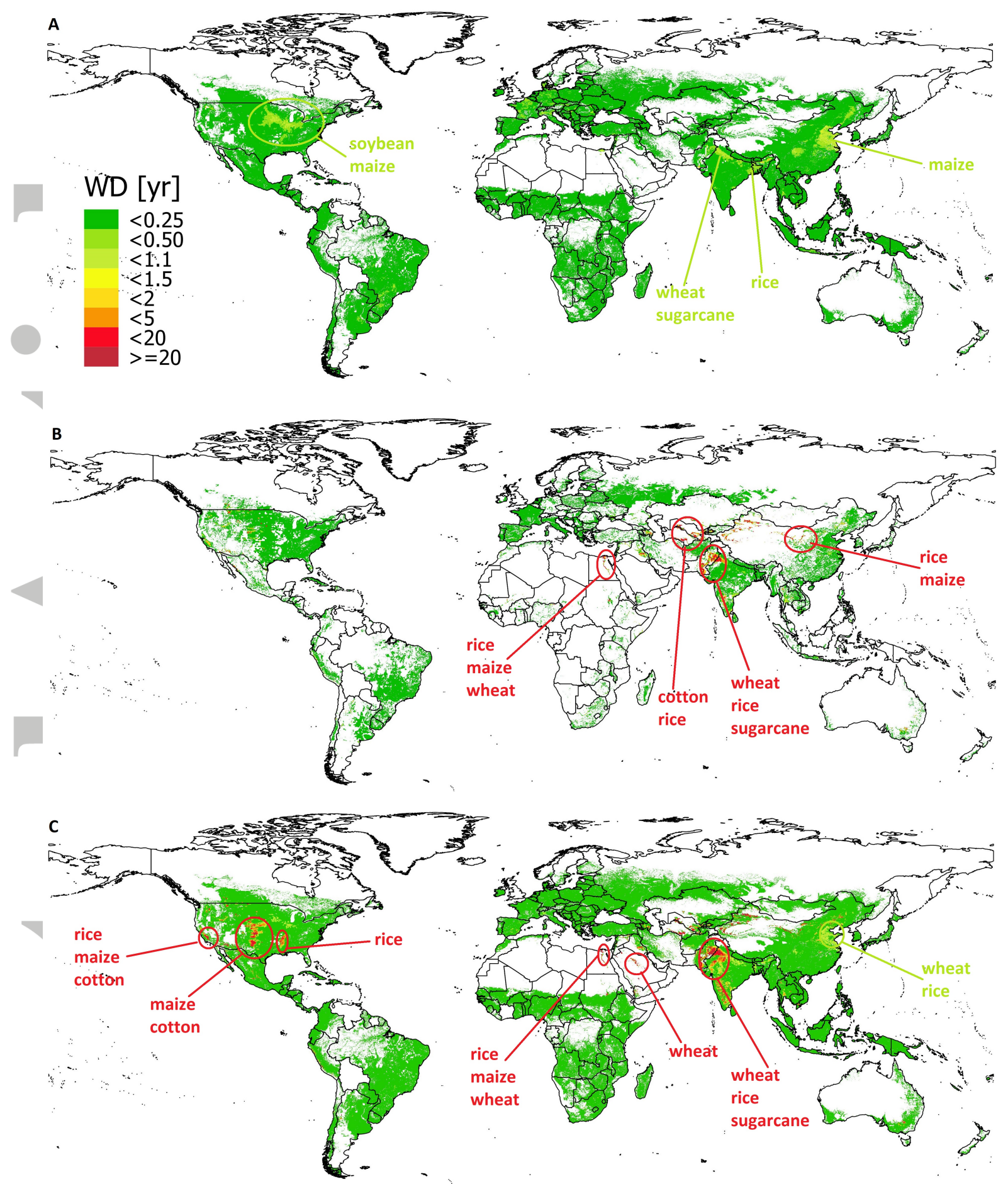

Figure 2. Repayment times to recover the water debt generated by annual crop production. $W D$ values at the grid level (5'x5' spatial resolution) is defined as the ratio of the source-specific water footprint to the source-specific water availability in the cell: green water use over annual soil moisture availability (A), surface water use over annual locally generated runoff (B), groundwater use over annual groundwater recharge $(\mathrm{C})$.

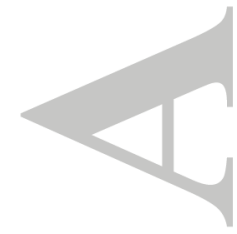

(C)2019 American Geophysical Union. All Rights Reserved. 

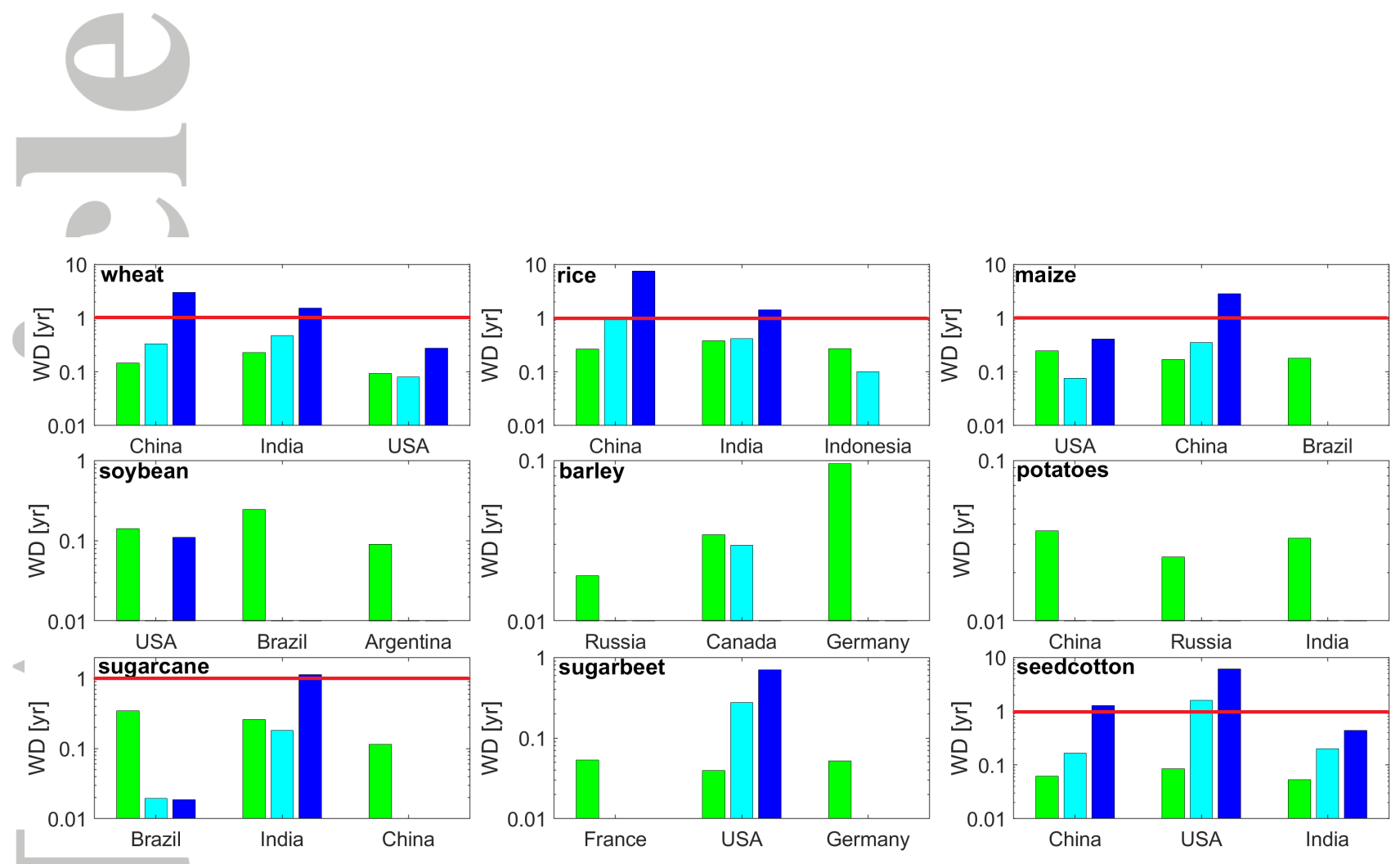

Figure 3. Average Water Debt for the top-three producing countries of each crop. National $W D$ is calculated as a production-weighted average of the gridded repayment time obtained for each crop and source. Note the different (logarithmic) scale of the y-axis in each panel. Green is for the soil moisture, light blue is for surface water and blue is for groundwater. The red line indicates $W D$ of 1 year and, thus, the boundary between sustainable and unsustainable water use. 


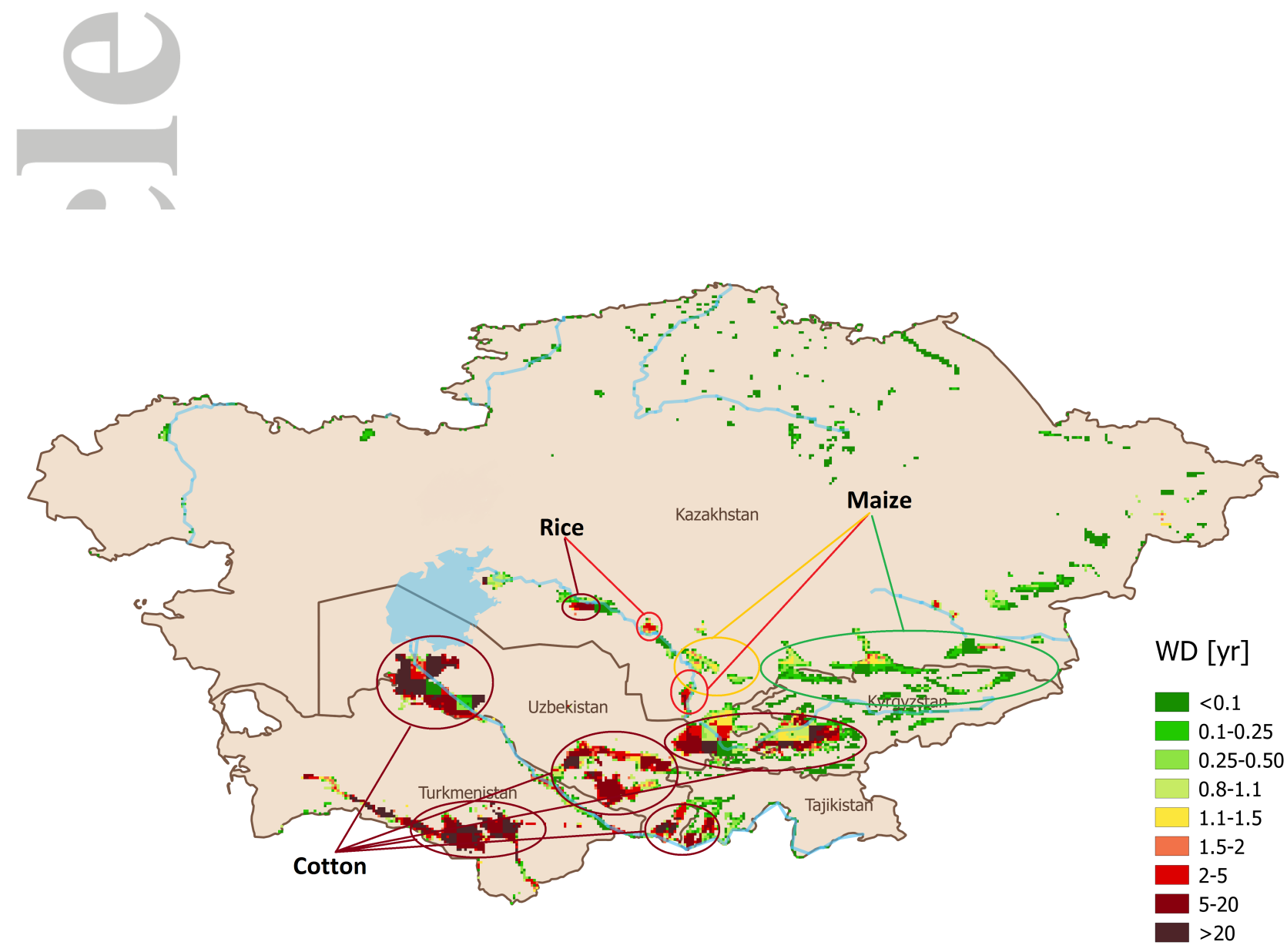

Figure 4. Water debt repayment time associated to crops' surface water footprint in the Amu Darya and Syr Darya basins. The color of each circle corresponds to the average repayment time needed to recover the water debt generated within the circle area. The linked crop name indicates the crop mostly responsible for the water debt in each area.

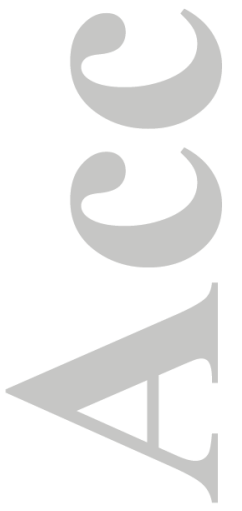

(C)2019 American Geophysical Union. All Rights Reserved. 

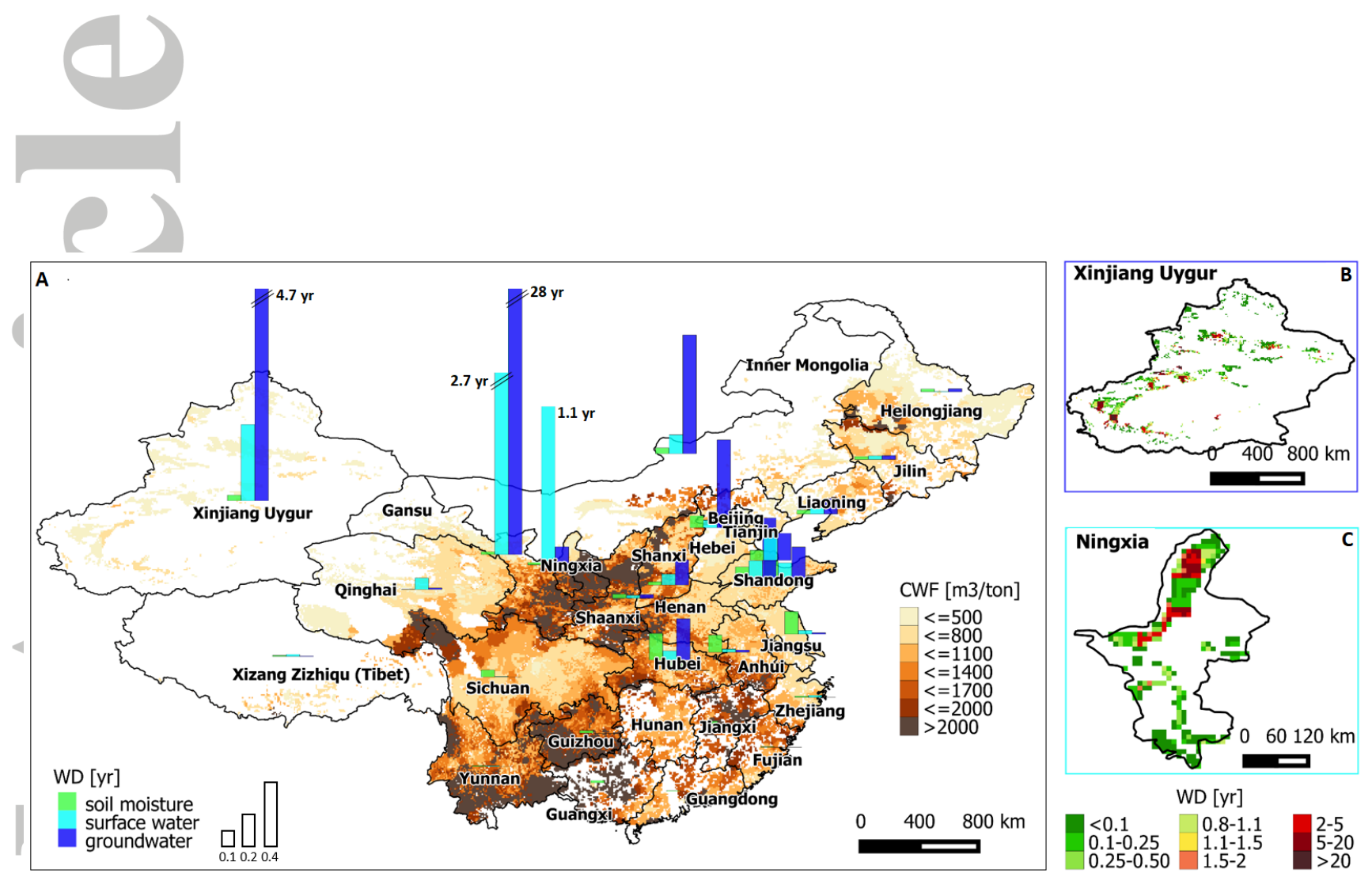

Figure 5. Water use efficiency and sustainability for wheat production in China.

(A) Gridded wheat water footprint per unit and histograms of water debt replsnishment times associated to the wheat green, surface, and ground water footprint at the province level. (B) Gridded $W D$ values to recover the ground water footprint across the Xinjiang Uygur province. (C) Gridded $W D$ values to recover the surface water footprint arisen in the Ningxia province. 